\title{
Academics' "Why" of Knowledge-Building for the Fourth Industrial Revolution and COVID-19 Era
}

\author{
Simon Bheki. Khoza ${ }^{1}$ \\ ${ }^{1}$ Discipline of Curriculum Studies \& Educational Technology, School of Education, University of KwaZulu-Natal, \\ Durban, South Africa \\ Correspondence: Simon Bheki. Khoza, Discipline of Curriculum Studies \& Educational Technology, School of \\ Education, University of KwaZulu-Natal, Durban, South Africa.
}

Received: July 9, 2020

Accepted: September 7, 2020

Online Published: September 30, 2020

doi:10.5430/ijhe.v9n6p247

URL: https://doi.org/10.5430/ijhe.v9n6p247

\begin{abstract}
Online teaching results in knowledge-building. Knowledge-building is the teaching and learning process that helps academics and students to generate specific personal values used to understand their personal identities. Academics have been forced by COVID-19 lockdowns to go online in teaching their students. The purpose of this study is to explore and understand academics' knowledge of teaching for knowledge building in two higher-education institutions (HEIs) (RSA and USA) during the COVID-19 era and the 4IR. Reflective activities, focus-group discussions, and semi-structured interviews were used for data generation. Purposive with convenience sampling was used to select the twenty most accessible academics to participate in this study. The findings reveal that this situation compelled the academics to self-actualise on their knowledge-building to address the "why" questions of teaching that help students to understand and address their needs. The self-actualization was framed by "technological pedagogical content knowledge" which produced societal, personal, and professional knowledge building. It was interesting to note that the USA HEI participants were supported by educational technologists, while the RSA HEI participants helped themselves. This was because the RSA HEIs do not have educational technology centres. Consequently, this study recommends a follow-up study that can qualitatively and quantitatively compare the two HEIs. In this way it can be established whether the success of online teaching and learning is influenced by the presence of educational technology centres. Educational technology centres have educational developers/technologists whose main responsibility is to collaborate with academics, various departments, and HEI units on a range of research/teaching/learning/assessment activities.
\end{abstract}

Keywords: 4IR; COVID-19, knowledge-building, LMS, self-actualization, SMS

\section{Introduction}

COVID-19 is a name given to the coronavirus of 2019, a virus first detected in Wuhan city in Hubei province of China. On Tuesday 31 December 2019, the Country Office of the World Health Organization (WHO) in China, received a report about an unknown virus. On 30 January 2020, WHO declared this situation caused by the virus a Public Health Emergency of international concern. Various other names that were given to the virus were 2019-nCoV, and severe acute respiratory syndrome coronavirus 2 (SARS-CoV-2). COVID-19, as the name used in this study, led to national lockdowns applying several stages, physical/social distancing, and the use of various technologies that were implemented in many countries, globally. National lockdowns were used to contain COVID-19, training citizens to practise personal hygiene, using various technologies as their life style.

For example, in South Africa (Republic of South Africa-RSA), on Monday 23 March 2020. president Cyril Ramaphosa announced a national lockdown. The lockdown was supposed to last 21 days, from Thursday 26 March to Thursday 16 April 2020. This lockdown was, however, extended to 30 April 2020, as Stage 5. Lockdown moved as from 1 May to Stage 4, and from 1 June 2020 to Stage 3, when sectors started to operate. In the United States of America (USA), various states responded to this uncertainty according their needs. COVID-19 and lockdown demanded higher-education institutions (HEIs), in line with all other sectors, to respond to this COVID-19 through online teaching, learning, research, and assessment processes/systems as the way of knowledge building. Owing to COVID-19, which demanded that all academics move fully online, academics were faced with use of Fourth Industrial Revolution (4IR) and old technological resources with unaligned technology features. Academics became frustrated, anxious, angry, and resistant through technostress or cyberphobia. Consequently, this study explored why 
academics educate for knowledge building in particular ways at two higher-education institutions (HEIs) situated in the RSA and the USA.

\section{The Fourth Industrial Revolution (4IR)}

Revolution is an unexpected, abrupt, unprecedented, and/or radical change that influences various sectors to perform their activities in new ways. The First Industrial Revolution (1760-1840) was characterised by the efforts of animals combined with those of people in order to facilitate communication, transportation, and production. This was also known as the Agrarian Revolution (Schwab, 2016). The First Industrial Revolution (1IR) was characterised by the construction of railroads and the invention of the steam engine, which facilitated mechanical production. The late $19^{\text {th }}$ century and into the early $20^{\text {th }}$ century, saw the arrival of the Second Industrial Revolution (2IR). The 2IR was characterised by mass production facilitated by assembly lines and electricity. The Third Industrial Revolution (3IR) which was called the computer or digital revolution started with the development of mainframe computing, the semiconductor (1960s), personal computing (1970s and 1980s), and the Internet (1990s) (Schwab, 2017). The Fourth Industrial Revolution (4IR) was formed by "the staggering confluence of emerging technology breakthroughs, covering wide-ranging fields such as artificial intelligence (AI), robotics, the internet of things (IoT), autonomous vehicles, 3D printing, nanotechnology, biotechnology, ... science, energy storage and quantum computing, to name a few" (Schwab, 2016, p. 7). The 4IR began at the turn of this century (Sutherland, 2020). Although the 4IR brings good opportunities for collaboration and connection to local and international resources that help us to address our personal needs, it comes with serious casualties such as limited prescribed security strategies, and an increasing gap between poor and rich people and others (Maynard, 2015; Mpungose, 2020b). This suggests that one has to be aware or understand one's needs and what the 4IR resources are capable of producing, before they are used in addressing needs in responsible ways that develop one's ability to deal with issues of security.

Higher-education institutions (HEIs), like other sectors, have taken advantage of these 4IR resources (4IR-Rs), using them for knowledge-building even during uncertainty or novelty (Khoza \& Biyela, 2020; Mpungose, 2020c). This has been evident when HEIs have been teaching, and researching even during COVID-19 lockdown, using the 4IR-Rs. Most of the resources used by HEIs during the COVID-19 lockdown exercised by various countries are learning management systems (LMSs), Skype, Zoom, WhatsApp, teacher robots (Bengaluru School in India), Google Team, and others (Khoza \& Biyela, 2020; Mpungose, 2020a).

\section{Knowledge-Building}

Knowledge building is the teaching and learning process that helps academics and students to generate specific personal values used to understand their personal identities (Mabuza \& Khoza, 2019; Makumane \& Khoza, 2020). Ike, Agbaeze, Udoh, and Adeleke (2019, p. 70) define knowledge-building as "an organizational process that aims to create a centralized knowledge source within the organization that acquires, assimilates, distributes, integrates, shares, retrieves and reuses the internal and external, explicit and tacit to bring innovation in the organization in the form of the product, people and organizational process". Knowledge-building is divided into professional or vertical, societal, or horizontal, and personal or pragmatic divisions, to frame the all-important teaching and learning or curriculum activities (Ceyhan et al., 2019; Khoza, 2018). According to Biesta (2015) and Mpungose (2020b), these divisions are also known as qualification or formal, socialisation or informal, and subjectification or non-formal, respectively. The 4IR-Rs are driven by these divisions in teaching, learning, and research, where the aims of the processes/systems are knowledge-building (Kamahina, Yakovenko, \& Daibova, 2019).

One the one hand, professional knowledge building addresses the descriptive "what" questions of teaching and learning (Fomunyam \& Khoza, 2018; Khoza, 2019). It asks: What objectives, content, technologies or resources, summative assessment/s, and other teaching or curriculum concepts are prescribed for the teaching systems? Studies (Hugo, 2016; Makumane, 2018; Tyler, 2013) argue that academics should search for these curriculum concepts from sources prescribing them. Academics should understand them, and use them to compile lesson plans or course outlines which will be prescribed before the teaching takes place. HEIs usually use LMSs to prescribe these curriculum concepts to guide students in learning. Objectives are short-term goals for teaching that represent subsections of the course content. Course content is the course knowledge that needs to be taught and assessed by academics in order to grade students. Professional knowledge-building uses summative assessment to establish whether students have mastered the course content through achievement of learning outcomes, based on the prescribed objectives.

According to Biesta (2015), in a study on good education, professional knowledge-building is applied when the aim of teaching is about high academic achievements that result in issuing qualifications or licences. Attention is more on whatever parts of the course content are missing from the student's mind, than on what the student has achieved. Published by Sciedu Press 
LMSs are used to the upload and display course content for the students to read whenever they need to do so. Skype and Zoom are mostly used to drill students with the course content through lecturing and other drilling of students. Teacher robots and other technologies are also produced and used to drill students with the course content. For example, Bengaluru School in India has been using a teacher robot successfully to teach content to more than 300 students in one class. Although professional knowledge-building promotes passive students, students achieve high academic marks. Students may not be able to apply the mastered content to their real-life situations. However, students may easily address professional needs, gain employment and scholarships because of high academic achievements (Budden, 2017; Pather, 2017).

On the other hand, societal knowledge-building addresses the operational "how" questions of teaching and learning (Khoza, 2019). It asks: How are technologies, activities, and peer-assessment strategies used to generate course content to be used in the achievement of learning outcomes? Students use various resources or technologies to engage learning activities. Such learning activities produce course content to be used in the achievement of learning outcomes (student goals). Societal knowledge-building uses technologies for student interaction and engagement. LMSs such as Canvas and others have incorporated social-media sites (SMSs): most students join HEIs with skills of using SMSs such as Facebook, WhatsApp, inter alia (Grossi, Elias, Chamon, \& Leal, 2018; Khoza \& Biyela, 2020). The academics' role is to facilitate learning through various technologies. For example, Zoom, Skype, WhatsApp, and other applications are used for discussions. These applications have added strength to the LMS discussion forums and other resources used by HEIs (Alaidarous \& Madini, 2016; Bozalek, Ng'ambi, \& Gachago, 2013). A study conducted by Nowak (2019, p. 262) on digital competences for the 4IR, argues for knowledge-building that provides students with abilities to address "the risks related to navigating through the cyberspace, searching, sectioning and gathering of information". Students may not use technologies to achieve very high academic marks if digital knowledge or abilities are only localised within a specific society. However, students may be very good at socialisation, promoted by their engagement with class activities and addressing societal needs (Bosch, 2009; Deng \& Tavares, 2013; Laeen, Ayati, Sani, \& Booreng, 2019). The 4IR-Rs demand that academics, students, and administrators undergo refresher training. Such will help the above-mentioned groups to understand digital technologies based on their needs, drawing from both professional and societal needs (Ilonga, Ashipala, \& Tomas, 2020).

A combination of professional and societal knowledge-building produces personal or pragmatic knowledge-building. Personal knowledge-building addresses individual needs through the personal "who" questions of teaching and learning (Mabuto, 2020; Zuma, 2019; Zuma., 2020). It asks: Who is teaching and/or learning (in terms of their identities)? Formative assessment, also known as assessment for learning, establishes the identities of those whose needs should be addressed through teaching and learning. Studies (Khoza, 2019; Mentz \& van Zyl, 2016; Wood \& Meyer, 2016) emphasise the importance of collaborative partnership. In this way, personal identities are established in order to promote a mutual working relationship between academics, students, and other involved stakeholders. Understanding one's personal identity promotes self-directed learning that results in self-actualization. Self-actualised people are highly creative, and problem-centred. Such people perceive reality efficiently, tolerate uncertainty, accept themselves and others for who they are, need privacy with democratic attitudes, and have high moral standards (Hoffman, 1988; Maslow, 1954). This suggests that there are specific values generated by addressing the personal "who" questions of teaching and learning before relevant 4IR-Rs are used. The discussions on the three divisions of knowledge-building suggest the importance of applying technological pedagogical content knowledge (TPACK) as a framework for knowledge-building (Mishra \& Koehler, 2006). Technological knowledge is driven by societal knowledge-building needs; pedagogical knowledge is driven by personal knowledge-building needs; and content knowledge is driven by professional knowledge-building needs (Khoza \& Biyela, 2020). Studies agree that the most important ingredient for successful teaching and learning that aims at knowledge-building for the 4IR and uncertainties or novelties (such as COVID-19, lockdown...), is the combination of these three divisions of knowledge-building (professional, societal, and personal). However, qualities or values found in academics that are capable of balancing the three divisions of knowledge-building are not yet known. It is for this reason that this study seeks to explore and understand academics' knowledge of teaching for knowledge-building.

Therefore, the next sections present the research purpose/objective with research questions, and the research design with methodology, as well as a discussion of findings, together with a conclusion.

\section{Research Purpose/Objective and Questions}

The purpose of this study is to explore and understand academics' knowledge of teaching for knowledge-building in two HEIs (RSA and USA) during the COVID-19 era, and the 4IR. The study addresses the following research 
questions:

A. What is the academics' knowledge of teaching for knowledge-building?

B. Why do academics have particular knowledge of teaching for knowledge-building?

\section{Research Design and Methodology}

This study applied an interpretive, quantitative case study to explore and understand academics' knowledge of teaching for knowledge-building. This is a case study of two HEIs situated in the RSA and USA, respectively. The study applied a qualitative interpretive case study because of its reality, which suggests that multi-truths are generated through dialogues between the researchers and participants (Kivunja \& Kuyini, 2017; Yin, 2011). The interpretive, qualitative case study method helped in this study to explore and understand academics' knowledge of teaching for knowledge-building through their reflections; such being exploratory and descriptive in nature (Creswell \& Creswell, 2018; Esau, 2017; Khoza, 2018). Participants and institutions were given pseudonyms for ethical reasons (Table 1). These were academics who attended workshops offered by the institution in supporting academics of this HEI with online teaching and learning. Some twenty academics were selected because of their ability to contribute to rich information that addressed the research questions (Creswell, 2014; Denzin \& Lincoln, 2018).

Table 1. Biographical Information on Participants

\begin{tabular}{|c|c|c|c|c|}
\hline Participant & Post Level & Race & Gender & HEI \\
\hline PT 1 & Lecturer & African & Female & RSA HEI \\
\hline PT 2 & Lecturer & African & Female & RSA HEI \\
\hline PT 3 & Lecturer & African & Male & RSA HEI \\
\hline PT 4 & Senior Lecturer & Coloured & Female & RSA HEI \\
\hline PT 5 & Senior Lecturer & Indian & Female & RSA HEI \\
\hline PT 6 & Senior Lecturer & Indian & Male & RSA HEI \\
\hline PT 7 & Associate Professor & White & Female & RSA HEI \\
\hline PT 8 & Associate Professor & African & Female & RSA HEI \\
\hline PT 9 & Associate Professor & African & Female & RSA HEI \\
\hline PT 10 & Professor & African & Male & RSA HEI \\
\hline PT 11 & Lecturer & White & Female & USA HEI \\
\hline PT 12 & Senior Lecturer & Indian & Female & USA HEI \\
\hline PT 13 & Senior Lecturer & White & Female & USA HEI \\
\hline PT 14 & Associate Professor & African & Female & USA HEI \\
\hline PT 15 & Associate Professor & African & Male & USA HEI \\
\hline PT 16 & Professor & Indian & Female & USA HEI \\
\hline PT 17 & Professor & White & Male & USA HEI \\
\hline PT 18 & Professor & African & Male & USA HEI \\
\hline PT 19 & Professor & White & Male & USA HEI \\
\hline PT 20 & Professor & White & Male & USA HEI \\
\hline
\end{tabular}

Twenty academics were selected for participation by purposive and convenient sampling. Participants had the ability to contribute rich data to the two research questions (Creswell, 2014; Denzin \& Lincoln, 2018). The academics were all part of the collaboration between the two HEIs. Ten participants were from the RSA HEI; and ten from the USA HEI - eight male and twelve female academics. There were nine African, one Coloured, four Indian, and six White academics. There were four lecturers, five senior lecturers, five associate professors, and six professors. Although there is scant literature on these variables, the interest of this study is on the exploration of academics' knowledge of teaching for knowledge-building in the two HEIs (RSA and USA) during COVID-19 and the 4IR era. Permission and ethical clearance to conduct the study were acquired from the HEIs, as well as gaining of informed consent from the participants. All actions were informed by ethical measures such as confidentiality, anonymity, and voluntary participation (Creswell \& Creswell, 2018; Kivunja \& Kuyini, 2017).

\section{Data Generation and Analysis}

The study used one-on-one semi-structured interviews (through Skype), focus-group discussions (FGD) (through Zoom), and reflective activities (through email). Both the interviews and FGD methods took approximately an hour 
each; and they were recorded, for easy transcription. The interviews and focus-group discussions helped the researcher to probe and rephrase the questions where necessary; such as in order to address Research Question Two that deals with "why" (philosophical question) (Khoza, 2019). Reflective activities helped to generate first-hand written information on lecturers' authentic feelings when they teach for knowledge-building to address Research Question One that deals with "what" (descriptive/professional question). The three methods were used for triangulation of data (Creswell, 2014; Denzin \& Lincoln, 2018). TPACK (technological/societal, pedagogical/personal, and content/professional) principles were used to generate the three themes of findings, along with their categories (Table 2). Dependability (consistency), credibility (truth value), transferability (applicability), and confirmability (neutrality), were used as the measures of trustworthiness (Creswell, 2014; Denzin \& Lincoln, 2018).

\section{Research Findings}

The findings presented in Table 2 are framed by three themes (societal, pragmatic, professional), with relevant categories. Each of the findings presented under the themes was answered (in writing) through the reflective activities, and confirmed/triangulated by means of the FGDs and interviews. The findings were also substantiated by means of discussions, in order to recontextualise them with relevant literature.

Table 2. Findings

\begin{tabular}{ll}
\hline THEMES & CATEGORIES \\
\hline THEME 1: Societal knowledge-building & - Digital technologies used \\
THEME 2: Pragmatic knowledge-building & - Goals \\
& - Assessment \\
& - Academic role \\
& - Teaching/learning environment \\
& - Community \\
& - Teaching strategies \\
THEME 3: Professional knowledge-building & - Content and time \\
\hline
\end{tabular}

\section{Discussion of Findings}

8.1 THEME 1: Societal Knowledge Building (Technological Knowledge)

8.1.1 Digital technologies used

Table 3. Type of Digital Technologies and Numbers of Users per HEI

\begin{tabular}{|c|c|c|}
\hline Digital technology & USA HEI Number uses & RSA HEI Number uses \\
\hline Canvas (LMS) & 10 & 00 \\
\hline Moodle (LMS) & 00 & 10 \\
\hline Facebook & 10 & 06 \\
\hline YouTube & 10 & 10 \\
\hline WhatsApp & 10 & 10 \\
\hline Facebook Messenger & 10 & 06 \\
\hline Weixin/WeChat & 10 & 00 \\
\hline Instagram & 10 & 06 \\
\hline Douyin/TikTok & 10 & 00 \\
\hline QQ & 10 & 00 \\
\hline Qzone & 10 & 00 \\
\hline Sina Weibo & 10 & 00 \\
\hline Reddit & 10 & 00 \\
\hline Snapchat & 10 & 00 \\
\hline Twitter & 10 & 06 \\
\hline Pinterest & 10 & 00 \\
\hline Kuaishou & 10 & 00 \\
\hline Linkedin & 10 & 06 \\
\hline
\end{tabular}


Table 3 indicates that the participants from the USA HEI had knowledge of Canvas LMS and various other types of SMSs, while the participants from the RSA HEI had knowledge of Modular Object-Oriented Dynamic Learning Environment (Moodle) and YouTube as their SMSs. However, six participants from the RSA HEI had knowledge of Facebook, Facebook Messenger, Instagram, Twitter, and Linkedin. The use of different LMSs (Moodle and Canvas) allowed the USA HEI participants to have more knowledge of SMSs than the participants from the RSA HEI. Moodle was developed in 1999 by Martin Dougiamas, a student at Curtin University of Technology in Australia. Canvas was developed in 2012 by Josh Coates Canvas, launched at Salt Lake City in Utah by an educational technology company supporting educational institutions. "Canvas uses a programming language more modern than Moodle, presenting an updated technology: cloud computing [includes SMSs], which represents an advantage over Moodle" (Grossi et al., 2018, p. 514). Figures 1 and 2 present activities and resources that were used by the participants from the two HEIs.

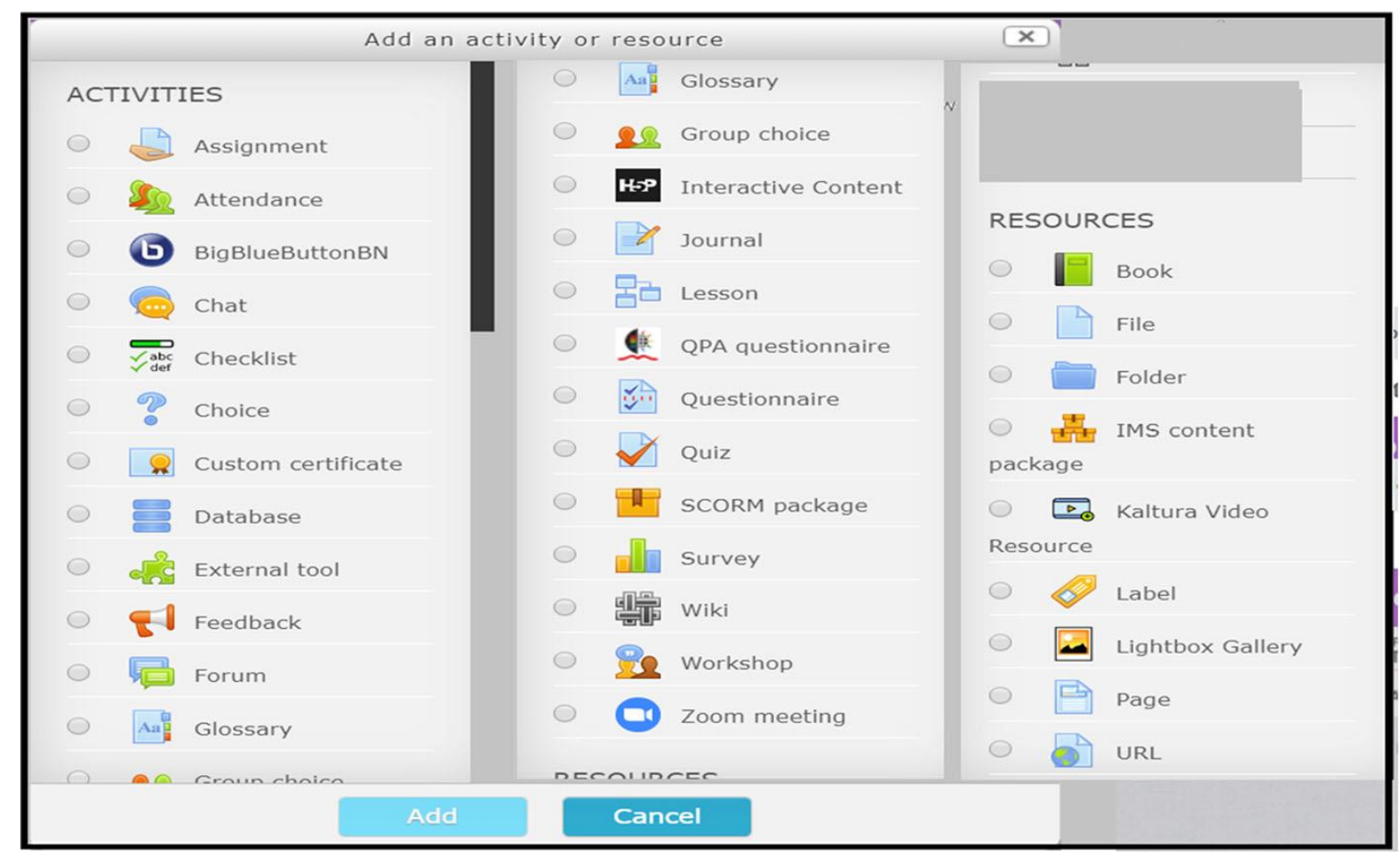

Figure 1. Moodle activities and resources 


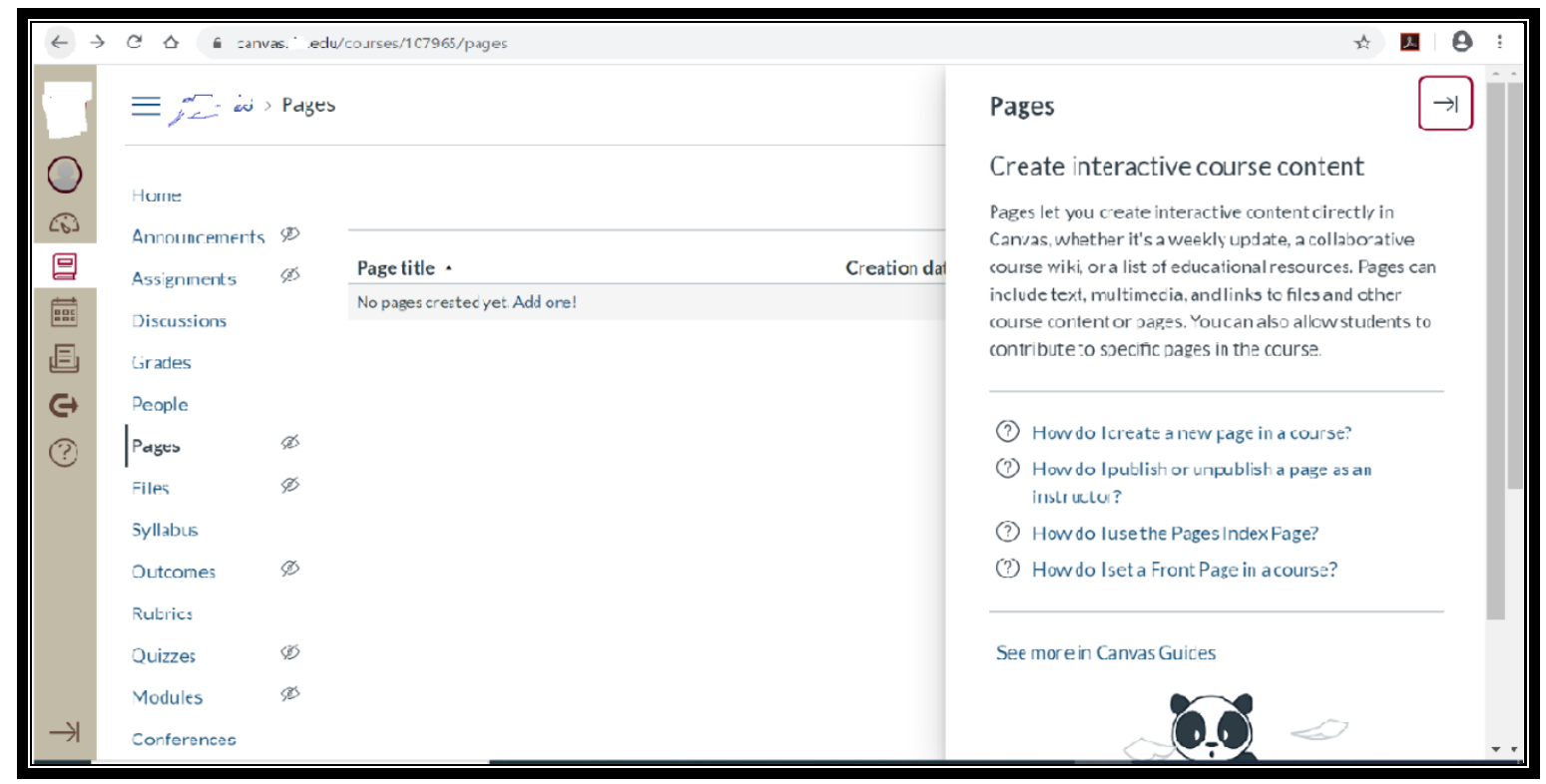

Figure 2. Canvas activities and resources

These activities were used by the participants for "assessment and resources for teaching course content and communicating with students as part of pedagogy" (PT 10 and others agreed). This suggests that the participants were aware that learning is about ideological-ware resources (experiences/theories/pedagogy) that drive digital technologies (Bozalek et al., 2015; Khoza, 2018). In other words, these are mind tools (conscious, subconscious, and unconscious) that cognitively manage digital technology users to select and use relevant digital technologies based on pedagogical needs of a course.

\subsection{THEME 2: Pragmatic Knowledge-Building (Pedagogical Knowledge)}

\subsubsection{Goals}

Goals involved in the teaching were aims, objectives, and learning outcomes. "We define and present aims as our long-term goals, objectives as our short-term goals, and learning outcomes as what our students should achieve at the end of our courses..." (PT 20, and others agreed). "We construct goals to reflect various levels of complexity (lower, middle, and higher) and needs of individuals, societies, and professions... Bloom's taxonomies are some examples of the frames we use in constructing the goals..." (PT 2, and others agreed). "We use Forum discussions, chats, Zoom, SMSs, and LMS resources for interactive teaching in order to achieve positive goals..." (PT 19, and others agreed). These accounts suggest that the participants' use of digital technologies was driven by specific goals. In other words, participants defined goals to lead their selection and use of digital technologies in teaching and learning. After teaching and learning, academics assess students to establish whether goals have been achieved. Assessment results should show that students have achieved learning outcomes, if the goals of a lesson/course have been achieved (Mabuza \& Khoza, 2019).

\subsubsection{Assessment}

Assessment is the collection, storing, and processing of information about students' knowledge, skills, and values, in order to provide feedback, or for grading the students. The participants used LMS activities that promoted peer, formative, and summative assessment. "We use different types of assessment such as quiz, video quiz, presentations by students, online assignments, questionnaires, discussion forum that allow our students to critiques one another's work before final assessment..." (PT 18, and others agreed). "We allow our students to do peer assessment in order to understand assessment processes before we administer any summative assessment..." (PT 15, and others agreed). "We use quiz, assignment and other LMS activities to establish where our students need support in order to provide relevant feedback..." (PT 11, and others agreed). These accounts suggest that the participants used different types of assessment as part of their teaching and learning pedagogy; and assessment is conducted before, during, and after the lessons. Participants further suggest the importance of combining peer, formative, and summative assessment as teaching, learning, and assessment taxonomies. In using these types of assessment as taxonomies, academics should understand the role they play (Makumane \& Khoza, 2020). 


\subsubsection{Academic Role}

The roles of the participants included those of instructor, facilitator, researcher, and assessor. "There are times where we have to instruct or demand students to master the content through quiz, multiple choice questions, etc... sometimes we use chat and other resources to facilitate learning..." (PT 9, and others agreed). "We sometimes see ourselves as researcher and assessor where we identify problematic issues to be researched by our students with us, report the findings/results and assess..." (PT 1, and others agreed). These accounts suggest the importance of understanding the various roles of academics. According to Budden (2017), Khoza (2018), and Kisaka (2018), the researcher role represents all other roles for academics: researchers may assess, instruct, facilitate, mediate, manage, organise, and perform any other roles. The accounts further suggest that the participants performed several roles, because they performed the role of being the researchers. However, the teaching and learning environment determines the role to be played by academics (Makumane \& Khoza, 2020; Shoba, 2018).

\subsubsection{Teaching/Learning Environment}

The participants created a blended teaching and learning environment (combination of online and face to face). "Although physical face to face contact has been difficult during lockdown of COVID-19, we have been successfully using Zoom and Skype for face to face teaching and learning..." (PT 5, and others agreed). "We sometimes use Kaltura video before we use Zoom for face to face..." (PT 13, and others agreed). These accounts suggest the importance of the face-to-face method in teaching and learning which can also be created by Zoom and other resources. In other words, even if academics create teacher robots, their presence will still be required where they have to invigilate an examination. "...examination was removed from the plan for semester one and this indicates that online teaching may not cover all assessment strategies of our choice... we have used only continuous assessment... We do not have educational technologists that support us with these...we rely heavily on other academics who have used these technologies before...” (PT 8, and all others from RSA HEI agreed). "...based on the support we always get from our educational technology centre we conduct any task even examination using relevant resources...". The accounts point to the importance of the role and contributions of educational technology centres. Participants were able to conduct studies to establish relevant pedagogies, theories, hardware, and software for online learning (Bozalek et al., 2015; Czerniewicz, 2018). Although the participants used a blended learning environment, online teaching and learning dominated the face-to-face teaching and learning. Such dominance may suggest the need for educational technologists to support the academics. This is especially so should COVID-19 demand that HEIs teach one hundred per cent online. However, students may not feel the need for academics if they have been facilitated to form learning communities.

\subsubsection{Community}

The participants used group presentations to encourage their students to form groups. "Other tasks given to our students require students to work in groups..." (PT 14, and others agreed). "We encourage our students to do independent studies and search relevant information from various sources... this may include consulting other colleagues so that they can become active and understand how to address their needs without heavily relying on us..." (PT 4, and others agreed). The accounts suggest the importance of building a learning community with members from different societies, in order to support academics. The accounts further suggest that teaching methods such as grouping and others may promote the learning community.

\subsubsection{Teaching Strategies}

The participants used various teaching strategies. "We use lecturing, drilling, question with answer, problem solving, case studies, project-based... but the nature of the content and students determines the strategy..." (PT 7, and others agreed). The accounts suggest the importance of understanding the course content in order to select and use relevant strategies.

\subsection{THEME 3: Professional Knowledge Building}

\subsubsection{Content and Time}

Time given to the academics to the delivery of content through HEI time-tables was important. "Using online teaching and learning, we could not cover all the sections/topics of our module content when we were affected by COVID-19 lockdowns... we had to revised our plans and time-tables according to our new university plan because we used 100\% online teaching for the first time... It was difficult to support the majority of our students because they come from disadvantaged background where they struggled even after they were given free data bundles by the university to connect online... The technical support of the majority of our students was worse because we were also struggling in the absence of educational technology centre in our institution... in turn this also affect the university 
subsidy from the government..." (PT 10, and all others from RSA HEI agreed). The content seems to drive every aspect of teaching and learning, even the online teaching, societies, and professionals. This was normal for the USA HEI academics because they have already been using online teaching and learning, supported by educational technology centres. "Each of our departments/sections has an educational technology centre that supports teaching and learning... as such we did not have a problem with content coverage because we are familiar with the online teaching and learning...business as usual... The nature of the content determines relevant pedagogy, and technologies... while the system is able to quantify student engagement with content, it does not provide qualitative measures..." (PT 20, and all others from the USA HEI agreed).

The accounts on the course content also emphasise the importance of educational technology centres that support academics in identifying relevant pedagogies, theories, and technologies driven by content. This suggests that learning is not only about content mastering, but it is also about student interaction, with the content based on individual, societal, and/or professional needs, in which the content will be applied. However, digital technologies used by the HEIs need to be developed in order to qualitatively measure student engagement with the course content. In their current form, technologies are only capable of quantifying the student engagement (Grossi et al., 2018). The findings reveal that teaching for knowledge building is guided by societal, professional, and personal needs that support the self-actualization of both academics and students.

\section{Conclusion with Implications}

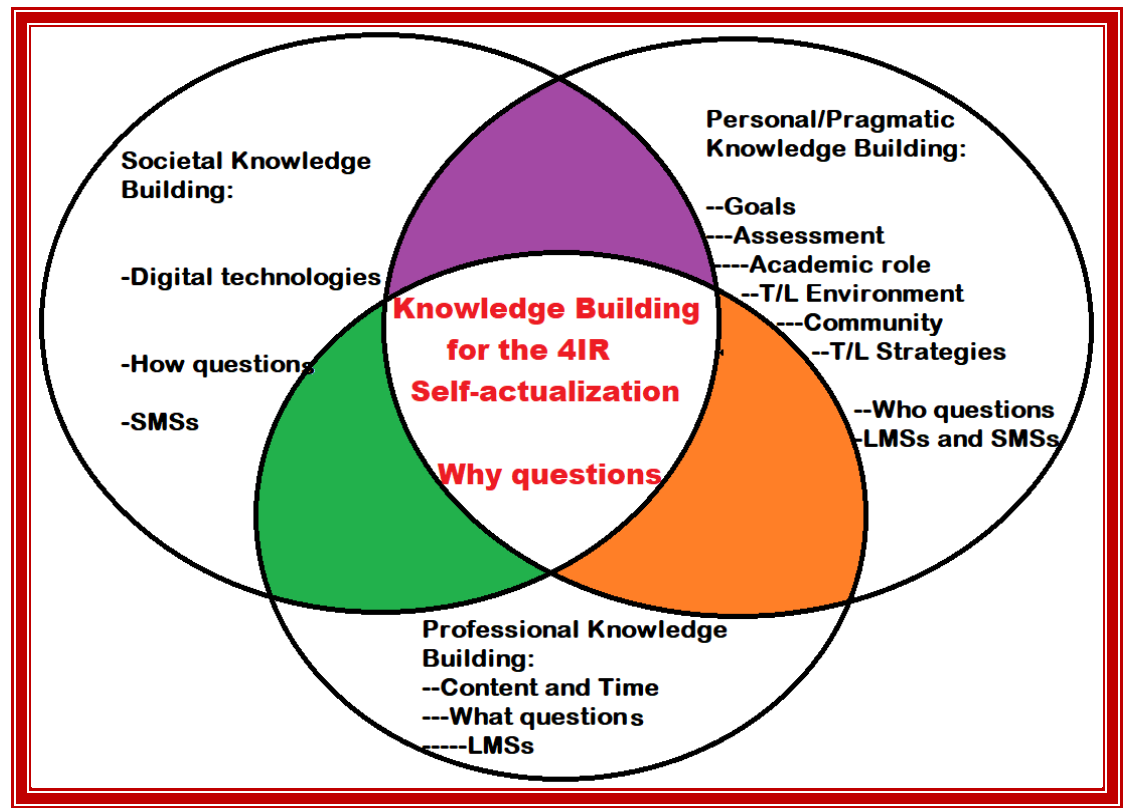

Figure 3. Knowledge building for the 4IR self-actualization

The findings, as summarised in Figure 3, conclude that, when academics teach, they are automatically engaged in knowledge-building that addresses the philosophical "why" questions about teaching and learning. This provides support for the self-actualization identity that emerges from individuals' tolerance of uncertainty or novelty. Individuals become problem-centred, as argued by Hoffman (1988), Khoza (2019), and others in support of Maslow (1954). The uncertainty or novelty in the participants' teaching was caused by COVID-19 lockdown of the HEIs. This unprecedented situation demanded the use of online teaching and learning environments. These online environments incorporated the 4IR-Rs that were new to the participants (academics). Not only did academics have to teach while they were locked in their living rooms, they had to use 4IR-Rs that were new to them. In other cases, academics survived by consulting their fellow academics in the absence of educational technologists' support. The participants were found to be highly creative, and problem-centred. They perceive reality efficiently, tolerated uncertainty, accepted themselves and others for who they are, needed privacy, having democratic attitudes and high moral standards. These values and qualities support what Maslow (1954) identifies as qualities of self-actualised individuals.

However, the academics were able to survive and self-actualise through the digital technologies (LMSs and SMSs for the how questions) they used in their teaching. Participants drove such with what they knew best, such as content 
with time management (professional for the what questions), and goals, assessment, role, environment, community, teaching strategies (pragmatic or pedagogy for the who questions). Consequently, the academics were able to address the philosophical "why" questions of their teaching and learning, through the interrogation of the "what", "how", and "who" questions.

Although the purpose of the study was not to compare the two HEIs, the findings revealed that the USA HEI managed the situation better than the RSA HEI because it had educational technologists or educational developers that supported the academics. This suggests that there is a need for a follow-up study that can qualitatively and quantitatively compare the two HEIs. Such a comparison would establish whether the success of online teaching and learning is influenced by the presence of educational technology centres. Educational technology centres have educational developers or educational technologists whose main responsibility is to collaborate with academics, various departments, and HEI units on a range of research, teaching, learning, and assessment activities.

\section{Acknowledgement}

Editor (Lydia Weight lydiaweight@gmail.com) for editing the article and the participants for participating.

\section{References}

Alaidarous, K., \& Madini, A. A. (2016). Exploring EFL Students' Perception in Blended Learning Environment in Saudi Technical Education Context. International Journal of Educational Investigations, 3(6), 69-81. Retrieved from https://www.researchgate.net/publication/312026564

Biesta, G. (2015). What is Education For? On Good Education,Teacher Judgement, and Educational Professionalism. European Journal of Education, 50(1), 75-87. https://doi.org/10.1111/ejed.12109

Bosch, T. E. (2009). Using online social networking for teaching and learning: Facebook use at the University of Cape Town. COMMUNICATIO, 35(2), 185-200. https://doi.org/10.1080/02500160903250648

Bozalek, V., Ng'ambi, D., \& Gachago, D. (2013). Converging institutional expertise to model teaching and learning with emerging technologies. Progressio, 35(2), 19-36.

Bozalek, V., Ng'ambi, D., Wood, D., Herrington, J., Hardman, J., \& Amory, A. (2015). Activity Theory, Authentic Learning and Emerging Technologies: Towards a Transformative Higher Education Pedagogy. Pretoria: Routledge. https://doi.org/10.4324/9781315771823

Budden, R. (2017). Exploration of factors that inform curriculum studies students to use e-resources in conducting Masters of Education dissertations at a South African university. (Doctor of Philosophy Full research), University of KwaZulu-Natal, Durban. (1)

Ceyhan, G. D., Thompson, A. N., Sloane, J. D., Wiles, J. R., Aksoy, S., \& Tillotson, J. W. (2019). The Socialization and Retention of Low-Income College Students: The Impact of a Wrap-Around Intervention. International Journal of Higher Education, 8(6), 249-26. https://doi.org.10.5430/ijhe.v8n6p249

Creswell, J. W. (2014). Qualitative inquiry and Research Design: Choosing among five approaches (3th ed.). California: SAGE Publications, inc.

Creswell, J. W., \& Creswell, J. D. (2018). Research Design: Qulitative, Quantitative, and Mixed Methods Approaches. London: SAGE Publications, Inc.

Czerniewicz, L. (2018). Inequality as Higher Education Goes Online. In N. B. Dohn, S. Cranmer, J. A. Sime, M. de Laat, \& E. Ryberg (Eds.), Networked Learning: Reflections and Challenges. Heidelberg: Springer Verlag.

Deng, L., \& Tavares, N. J. (2013). From Moodle to Facebook: Exploring students' motivation and experiences in $\begin{array}{lllll}\text { online communities. } & \text { Computers } \quad \& \quad \text { Education, 68(2013), 167-176. }\end{array}$ https://doi.org/10.1016/j.compedu.2013.04.028

Denzin, N. K., \& Lincoln, Y. S. (2018). The SAGE Handbook of Qualitative Research (5th ed.). London: SAGE Publications, Inc.

Esau, O. (2017). Emancipatory action research. In L. Ramrathan, L. Le Grange, \& P. Higgs (Eds.), Education Studies: for Initial Teacher Development (pp. 444-455). Cape Town: Juta \& Company (Pty) LTD.

Fomunyam, K. G., \& Khoza, S. B. (2018). Managing Curriculum Politics of Responsiveness in a Cameroonian Universty. International Journal of Management and Applied Science, 4(2), 49-57. 
Grossi, M. G. R., Elias, M. C. A., Chamon, C. M., \& Leal, D. C. C. (2018). The Educational Potentialities of the Virtual Learning Environments Moodle and Canvas: A Comparative Study. International Journal of Information and Education Technology, 8(7), 514-519. https://doi.org/10.18178/ijiet.2018.8.7.1091

Hoffman, E. (1988). The right to be human: A biography of Abraham Maslow. New York: Jeremy P. Tarcher, Inc.

Hugo, W. (2016). The what and how in scripted lesson plans:.... Journal of Education, 2016(66), 1-12.

Ike, R. N., Agbaeze, E. K., Udoh, B. E., \& Adeleke, B. S. (2019). Challenges Associated with the Implementation of Knowledge Management in Nigerian Tertiary Institutions. International Journal of Higher Education, 8(8), 70-76. https://doi.org/10.5430/ijhe.v8n8p70

Ilonga, A., Ashipala, D. O., \& Tomas, N. (2020). Challenges Experienced by Students Studying through Open and Distance Learning at a Higher Education Institution in Namibia: Implications for Strategic Planning. International Journal of Higher Education, 9(4), 116-127. https://doi.org/10.5430/ijhe.v9n4p116

Kamahina, R. S., Yakovenko, T. V., \& Daibova, E. V. (2019). Teacher's Readiness to Work under the Conditions of Educational Space Digitalization. International Journal of Higher Education, 8(7), 79-83. https://doi.org/10.5430/ijhe.v8n7p79

Khoza, S. B. (2018). Can Teachers' Reflections on Digital and Curriculum Resources Generate Lessons? Africa Education Review, 1(2018), 1-16. http://doi.org/10.1080/18146627.2017.1305869

Khoza, S. B. (2019). Lecturers' Reflections on Curricular Spider Web Concepts Transformation Strategies. In E. N. Ivala \& C. L. Scott (Eds.), Transformation of Higher Education Institutions in Post-Apartheid South Africa (Vol. 1, pp. 15-26). New York: Routledge-Taylor \& Francis Group. https://doi.org/10.4324/9781351014236-2

Khoza, S. B., \& Biyela, A. T. (2020). Decolonising Technological Pedagogical Content Knowledge of First Year Mathematics Students. Education and Information Technologies, 25(4), 2665-2679. https://doi.org/10.1007/s10639-019-10084-4

Kisaka, S. T. (2018). An Exploration of the Use of Moodle in Teaching MED Students at a University in Kenya. (Doctor of Philosophy), University of KwaZulu-Natal, Durban.

Kivunja, C., \& Kuyini, A. B. (2017). Understanding and Applying Research Paradigms in Educational Contexts. International Journal of Higher Education, 6(5), 26-41. https://doi.org/10.5430/ijhe.v6n5p26

Laeen, S. J., Ayati, M., Sani, H. J., \& Booreng, M. A. (2019). A Teachers Perception on Localization of Curriculum with Emphasis on Social Studies Lesson. International Journal of Higher Education, 8(7), 84-94. https://doi.org/10.5430/ijhe.v8n7p84

Mabuto, M. P. (2020). Educators Enacting Non-Formal Education Policy - Case of Three Schools in Masvingo District, Zimbabwe - An Exploration. (PhD), University of KwaZulu-Natal, Durban.

Mabuza, D. C., \& Khoza, S. B. (2019). Educators' reflections of the instructional time in JC integrated consumer science curriculum. International Journal of Home Science, 5(1), 1-7.

Makumane, M. A. (2018). Educators' Enactment Strategies of the French Integrated Curriculum: An Action Research of Lesotho Educators. (Doctor of Philosophy Full Thesis), University of KwaZulu-Natal, Durban.

Makumane, M. A., \& Khoza, S. B. (2020). Educators' Reasonings and their Effects on Successful Attainment of Curriculum Goals. South African Journal of Higher Education, 34(2), 95-111. https://doi.org/10.20853/34-2-3428

Maslow, A. H. (1954). Motivation and personality. New York: Harper and Row.

Maynard, A. D. (2015). Navigating the fourth industrial revolution. NATURE NANOTECHNOLOGY, 1O(2), 1005-1006. https://doi.org/10.1038/nnano.2015.286

Mentz, E., \& van Zyl, S. (2016). Introducing cooperative learning: students' attitudes towards learning and the implications for self-directed learning. Journal of Education, 2016(64), 79-109.

Mishra, P., \& Koehler, M. J. (2006). Technological Pedagogical Content Knowledge: A new framework for teacher knowledge. Teachers College Record, 108(6), 1017-1054. https://doi.org/10.1111/j.1467-9620.2006.00684.x

Mpungose, C. B. (2020a). Beyond limits: Lecturers' reflections on Moodle uptake in South African universities. Education and Information Technologies, 2020(4), 1-20. https://doi.org/10.1007/s10639-020-10190-8 
Mpungose, C. B. (2020b). Is Moodle a Platform to Decolonise the University Curriculum? Lecturers' Reflections. Africa Education Review, 17(1), 100-115. https://doi.org/10.1080/18146627.2018.1479645

Mpungose, C. B. (2020c). Is Moodle or WhatsApp the preferred e-learning platform at a South African university? First-year students' experiences. Education and Information Technologies, 25(2), 927-941. https://doi.org/10.1007/s10639-019-10005-5

Nowak, B. M. (2019). The Development of Digital Competence of Students of Teacher Training Studies-Polish Cases. International Journal of Higher Education, 8(6), 262-266. https://doi.org/10.5430/ijhe.v8n6p262

Pather, R. (2017). Library spaces in higher education: exploring academics' understanding. (Doctor of Philisophy Full thesis), University of KwaZulu-Natal, Durban. (1)

Schwab, K. (2016). The Fourth Industrial Revolution. Cologny: World Economic Forum®.

Schwab, K. (2017). The fourth industrial revolution. Raglan: Currency.

Shoba, M. E. (2018). Exploring Teachers' Experiences of Teaching English-Speaking Skill to Second Language Learners in Three KwaNdengezi Township Primary Schools. (Doctor of Philosophy Full Thesis), University of KwaZulu-Natal, Durban.

Sutherland, E. (2020). The Fourth Industrial Revolution - The Case of South Africa. South African Journal of Political Studies, 47(2), 233-252. https://doi.org/10.1080/02589346.2019.1696003

Tyler, R. W. (2013). Basic principles of curriculum and instruction. Illinois: University of Chicago press. https://doi.org/10.7208/chicago/9780226086644.001.0001

Wood, L., \& Meyer, M. (2016). A participatory approach to servicelearning in creative arts education: a winwin learning opportunity for campus and community? Journal of Education, 2(65), 31-54.

Yin, R. K. (2011). Qualitative Research from Start to Finish. New York: The Guilford Press.

Zuma, S. (2019). Reimaging Moodle as an Effective Learning Management System through the Experiences of Geography Lecturers at a Selected South African university. (PhD), University of KwaZulu-Natal, Durban.

Zuma., T. H. (2020). Exploring Lecturers' Understanding of Turnitin Utilisation in Assessing Mathematics at a South African University. (PhD), University of KwaZulu-Natal, Durban.

\section{Copyrights}

Copyright for this article is retained by the author(s), with first publication rights granted to the journal.

This is an open-access article distributed under the terms and conditions of the Creative Commons Attribution license (http://creativecommons.org/licenses/by/4.0/). 